Research Article

www.ijrap.net

\title{
A CLINICAL STUDY TO COMPARE THE EFFICACY OF DHATKYADI TAILA PICHU AND LODHRADI VARTI IN SHWET PRADAR
}

\author{
Megha Gupta*
}

Assistant Professor, Prasuti Tantra avum Stri Rog Deptt, Mandsaur Institute of Ayurved Education \& Research. Address-A-61, Suryan hope town, Chandkheda, Ahmedabad, Gujarat-382424, India

Received on: 06/10/17 Accepted on: 23/11/17

*Corresponding author

E-mail: meghaguptaayu@gmail.com

DOI: 10.7897/2277-4343.0919

\section{ABSTRACT}

Shwet Pradar in Ayurveda, including all physiological and pathological vaginal discharges in modern science is the most common and distressing problem seen amongtoday's women. The present treatment consists of topical and systemic antibiotics, antifungal preparations which have many side effects and also disrupt the normal vaginal flora leading to recurrent infection. So, Sthanika Chikitsa mentioned in Ayurvedic classics for Stri Roga has been considered. The present study was carried out to evaluate the effect of Sthanika Chikitsa-Yoni Pichuand Yoni Vartiin Shwet Pradar and to compare their efficacy in Shwet Pradar. The therapeutic protocol includes 40 patients of Shwet Pradar in 2 Groups. Group I was given Dhatkyadi Taila Pichu $15 \mathrm{ml}$ vaginally for 7 days at night and Group II was given Lodhradi Varti 3 gm vaginally for 7 days at night.The treatment was repeated after 15 days of drug free period, if required. Overall effect of therapy was seen more in Group I than Group II. Group I treated with Dhatkyadi Taila Pichu showed more significant results than Group II treated with Lodhradi Varti in discharge per vagina, congestion of cervix and wet film examination statistically and clinically in pruritus and foul smell also. Dhatkyadi Taila was seen as a better drug than LodhradiVarti in management of Shwet Pradar.

Keywords: Shwet Pradar, Sthanika Chikitsa, Yoni Pichu, Yoni Varti, Dhatkyadi Taila, Lodhradi Varti

\section{INTRODUCTION}

Woman has a unique existence in the universe created by the God. Women health is the pivot not only for the healthy and happy status for her family, rather to the whole society or even to the nation at large. In the present scenario women are competing with men in all types of careers as had never before and they are equally under stress. Also many predisposing factors like unbalanced and irregular diet, mental tension, poor personal hygiene, lack of sanitation, imprudence during menstruation and injudicious use of contraceptives attributes to many gynecological disorders. Amongst these problems, abnormal vaginal discharge is the most common factor which becomes an obstacle in women freedom. Nearly $70 \%$ of women in the society suffer from this condition. Abnormal vaginal discharge may be physiological or pathological, is a symptom of various diseases. Sometimes this symptom is so severe that it over shadows the actual disease and women seek for the treatment of this symptom only. The main problems seen associated with leucorrhoea are mental stress, problem of sexual anxiety and even sometimes fear of carcinoma or failure to conceive, moreover it also causes local inconvenience to the patient.

In Ayurvedic literature, leucorrhoea is not mentioned as a separate disease entity however excessive white vaginal discharge called as Shwet Pradar in Ayurveda is quoted as a symptom in multiple gynecological problems. Charaka also described Chikitsa of Pandura Asrigdara ${ }^{1}$ which is mentioned as Shwet Pradar in Chakrapani Tika. ${ }^{2}$
Current medical therapy includes the use of systemic or topical antibiotics and antifungal preparations which may temporarily reduce infection but have many systemic side effects $\&$ often disrupt the balance of normal vaginal flora, leading to recurrent infection. There is description of specialized local therapy i.e. Sthanika Chikitsa in Ayurveda in Stri Roga which includes Yoni Dhavana, Pichu Dharana, Yoni Dhupana, Uttara Basti etc. which have many benefits. The importance of Yoni Varti in Kaphaja Roga is told by Acharya Charaka in Chikitsa Sthana $30^{\text {th }}$ chapter ${ }^{3}$. Thus, under present study, Lodhradi Varti ${ }^{4}$ and Dhatkyadi Taila Pichu ${ }^{5}$ were selected in Shwet Pradar.

\section{MATERIALS \& METHODS}

The therapeutic protocol in the present study includes 40 patients in two different groups, selected from OPD of R.G.G.P.G. Ayurvedic College and Hospital, Paprola irrespective of caste and religion. Detailed history was taken according to the proforma prepared for the study incorporating all the relevant points from both Ayurvedic as well as modern views.

This was an open randomized clinical trial. Total 42 patients were registered after obtaining informed consent and categorized into Group I \& II in present clinical study and the drug was given to all the patients in the dose and formulation stated ahead. Out of 42 patients, 8 patients dropped out while 34 turned for the follow up. 
Table 1: Drug formulation, route, dose and duration of both Groups

\begin{tabular}{|c|c|c|c|c|c|}
\hline Group & Drug & Formulation & Route & Dose & Duration \\
\hline I & Dhatkyadi Taila & Yoni Pichu & Vaginal & $15 \mathrm{ml}$ & 7 days at Night \\
\hline II & Lodhradi Varti & Yoni Varti & Vaginal & 3 gm & 7 days at Night \\
\hline
\end{tabular}

There were 2 follow ups one after 7 days and second after 15 days of drug free period which was repeated, if required, in the same manner.

\section{Statistical Analysis}

The obtained data was analyzed statistically and expressed in terms of Mean, Standard deviation $( \pm \mathrm{SD})$ and Standard error $( \pm \mathrm{SE})$. Appropriate ' $\mathrm{t}$ ' test was applied to observe the significance of results obtained after treatment and regarding inter group comparison of drug effects.

The obtained results were interpreted as:

- Insignificant result $\quad p>0.05$

- Significant $\quad \mathrm{p}<0.01$

- Highly significant $\quad \mathrm{p}<0.001$

The level of significance was noted and interpreted accordingly.

\section{RESULTS}

Group I, treated by Dhatkyadi Taila Pichu, the relief in symptoms were as follows:-

1. Pruritus - The mean score before treatment was 1.429 which decreased to 0.429 after the completion of the treatment. This $70 \%$ relief was statistically significant (p $<0.05)$.

2. Discharge per Vaginum - The mean score before treatment was 1.444 , which reduced to 0.333 after treatment. Relief was $76.9 \%$ which was highly significant $(\mathrm{p}<0.001)$.

3. Foul Smell - The mean score before treatment was 1.167 which decreased to 0.500 after the completion of the treatment. This $57.2 \%$ relief was statistically significant ( $p$ $<0.05)$.

4. Low Backache - The mean score before treatment was 1.455 which decreased to 1.091 after the completion of the treatment. This $25 \%$ relief was statistically significant (p $<0.05)$.

Effect of Dhatkyadi Taila Pichu on signs of 18 patients in Group-I

Vagina - The mean score before treatment in vaginal congestion was 1.000 which reduced to 0.250 after treatment. Relief was $75 \%$ which was statistically not significant ( $p>0.05$ ). Cervix - The mean score before treatment in cervical congestion was 1.000 which reduced to 0.200 after treatment. Relief seen was $80 \%$ which was statistically significant ( $p$ $<0.05)$.

Effect of Dhatkyadi Taila Pichu on wet film examination (W.F.E.) of 18 patients in Group -I

The mean score before treatment was 2.500 which decreased to 1.143 after treatment. Relief was $54.3 \%$ which was statistically highly significant $(\mathrm{p}<0.001)$.

Group II, treated by Lodhradi Varti, the relief in symptoms are as follows

1. Pruritus - the mean score before treatment was 1.800 which decreased to 1.500 after the completion of the treatment. This $16.7 \%$ relief was statistically not significant $(p>0.05)$.
2. Discharge per Vaginum - The mean score before treatment was 1.625 , which was reduced to 0.875 after treatment. Relief was $46.2 \%$ which was highly significant $(\mathrm{p}<0.001)$.

3. Foul Smell - the mean score before treatment was 1.000 which decreased to 0.571 after the completion of the treatment. This $42.9 \%$ relief was statistically not significant ( $p>0.05)$.

4. Low Backache - the mean score before treatment was 2.000 which decreased to 1.778 after the completion of the treatment. This $11.1 \%$ relief was statistically not significant $(\mathrm{p}>0.05)$.

Effect of Lodhradi Varti on signs of 16 patients in Group -II

Vulva - The mean score before treatment in vulval congestion and vulval skin excoriations was 1.000 which remains same after treatment showing no relief and was statistically not significant $(\mathrm{p}>0.05)$.

Vagina - The mean score before treatment in vaginal congestion was 1.000 which reduced to 0.500 after treatment. Relief was $50 \%$ which was statistically not significant ( $p>0.05$ ).

Cervix - The mean score before treatment in cervical congestion was 1.000 which reduced to 0.833 after treatment. Relief seen was $16.7 \%$ which was statistically not significant (p $>0.05$ ).

Effect of Lodhradi Varti on wet film examination (W.F.E.) of 16 patients in Group -II

The mean score before treatment was 2.714 which decreased to 2.143 after treatment. Relief was $21 \%$ which was statistically significant $(\mathrm{p}<0.05)$.

Comparison between Results of Symptoms of Group I \& Group II

1. Pruritus - Group-I shows $53.3 \%$ more relief than Group-II; which was statistically not significant.

2. Discharge $\mathbf{P} / \mathbf{V}$ - Group-I shows $30.7 \%$ more relief than Group-II; which was statistically significant.

3. Foul Smell - Group-I shows $14.3 \%$ more relief than Group-II; which was statistically not significant.

4. Low Backache - Group-I shows $13.9 \%$ more relief than Group-II; which was statistically not significant.

\section{Comparison between Results of signs of Group I and Group} II

1. Vaginal Congestion - Group-I shows $25 \%$ more relief than Group-II; which was statistically not significant.

2. Cervical Congestion - Group-I shows $63.3 \%$ more relief than Group-II; which was statistically not significant.

Wet film examination - Group-I shows $33.3 \%$ more relief than Group-II; which was statistically significant.

\section{Overall Effect of Therapy}

\section{Overall Effect of Dhatkyadi taila pichu In Group-I}

Out of 18 patients, 7 patients i.e. $38.9 \%$ were markedly improved, $22.2 \%$ patients i.e. 4 patients were moderately improved, 5 patients i.e. $27.8 \%$ were improved mildly and $11.1 \%$ patients showed no effect. 


\section{Overall Effect of Lodhradivarti in Group-II}

Out of 16 patients, 1 patient i.e. 6.25\% was markedly improved, $18.75 \%$ patients i.e. 3 patients were moderately improved, 4 patients i.e. $25 \%$ were improved mildly while $50 \%$ patients showed no effect.

\section{DISCUSSION}

Shwet Pradar is predominantly a Kaphavataja disorder. Kapha can be considered as main causative factor by its vitiated Snigdha and Pichchila properties. Pitta and Kapha Doshas vitiation does not occur without the involvement of Vata Dosha ${ }^{6}$. Moreover, any type of Yoni Roga does not occur without the involvement of Vata Dosha ${ }^{7}$, vitiation of Vata occurs chiefly by its Chala Guna. Though Kapha and Vata seem to be the leading Doshas responsible for Shwet Pradar but the role of Pitta cannot be neglected here as any disease in Ayurveda involves all three Doshas though predominance varies $^{8}$. Pitta is vitiated mainly by its Visra, Sara and Drava Guna. In Shwet Pradar, Krimi also affects the three Doshasin Yoni and Garbhashaya. So, Shwet Pradar can be considered as a Kaphavata Pradhana Tridoshaja Vyadhi. Therefore Kapha-Vata Shamaka as well as Krimighna (antimicrobial) Dravya would be beneficial in the Chikitsa (treatment) of present disease.

\section{Probable Mode of Action of Sthanika Chikitsa ${ }^{9}$}

- The vagina absorbs water, electrolytes and substances of low molecular weights. absorption and re absorption are believed to occur mainly in the lateral recesses of the lower vagina.

- Vaginal mucosa absorbs lipophilic drugs.

- The vaginal wall and the tissues around are extremely vascular thus this must be also facilitating the absorption of drugs through the vagina.

The theory of probiotics (friendly bacteria), such as acidophilus are normally found in the vagina. When colonies of these organisms are present, it is difficult for unfriendly organisms such as Candida to become established. Probiotic supplements can help restoring a normal balance of vaginal organisms reducing the chance of developing a vaginal infection.

\section{Probable Mode of Action of Taila Pichu9}

- Pichu helps the medicine to remain at the site for a longer period for better action.

- It performs the action with the help of the drugs used in the preparation of Taila.

- It diminishes the chances of infection in the genital tract, as Tailais YoniVishodhana ${ }^{10}$.

- It has Vranaropaka properties.

- Taila or Sneha is Vataghna ${ }^{10-11}$.

\section{Probable Mode of Action of Vartis}

- Vartis are meant for Shodhana Karma.

- Vartis are hygroscopic they absorb the Sravas (discharges).

- Vartis show the action according to the drugs it contains ${ }^{9}$.

Probable mode of action of formulations is based on pharmacodynamic properties (Rasapanchaka) of drugs in Ayurveda. Dhatkyadi Taila acts by its Tridoshashamaka, Stambhaka, Sravashoshaka, Krimighna, Kandughna,Shothhara, Vranaropaka, Srotoshodhaka and Yonishodhaka properties. Lodhradi Varti acts by its Tridoshashamaka, Stambhaka, Sravashoshaka, Vranaropana and Kapha Shodhana properties.
Dhatkyadi Taila is better than Lodhradi Vartias :-

- Taila is Yonivishodhaka ${ }^{10}$.

- Taila is Sukshma and Vyavayi so provides a medium to drugs for easy penetration in vagina ${ }^{12}$.

- Taila is described as "marutaghnamna cha sleshmvardhanam ${ }^{10}$.

- Dhatkyadi Taila contains Katu and Tikta Rasa Dravyas also which are not present in Lodhradi Varti, which has Krimighna, Kandughna, Srotoshodhana and Shothharaproperties.

According to modern pharmacology, they work as follows:

Most of the drugs have tannins, flavonoids, saponins, triterpenoids which have antimicrobial, antifungal, astringent, anti-oxidant, anti-inflammatory properties so when applied externally reduces the symptoms and signs. Polyphenolic compounds, flavonoids exhibit potent anti-inflammatory and astringent properties so have excellent wound healing effect.

Though oral therapy was not given to the patients along with the local therapy but they were advised for Nidana Parivarjana and to follow the advice given to them during the clinical trial.

\section{CONCLUSION}

Group I treated with Dhatkyadi Taila showed more significant results than the Group II treated with Lodhradi Varti in discharge per vagina, congestion of cervix and wet film examination statistically and clinically in pruritus and foul smell also. Thus, Dhatkyadi Taila was seen as a better drug than Lodhradi Varti in management of Shwet Pradar.

\section{ACKNOWLEDGEMENT}

It is a privilege for me to express my deep sense of gratefulness and indebtedness to my revered, benevolent teacher and my Guide Prof. (Dr.) Eena Sharma, H.O.D, Dept. of Prasuti Tantra avumStriRoga, R.G.G.P.G. Ayurvedic College \& Hospital, Paprola for her guidance and supervision to complete this clinical study.

\section{REFERENCES}

1. Charaka, Charaka Samhita with Vidyotini Hindi commentary part II by Pt. Kashinatha Shastri and Dr. Gorakhanath Chaturvedi, Reprint 2009, Chaukhambha Bharati Academy, Varanasi, Chikitsa Sthana Adhyaya 30/116-121

2. Charaka, Charaka samhita, Ayurveda dipika's Ayusihindi commentary part II by Acharya Siddhi Nandana Mishra edited by Vd. Harish Chandra Singh Kushwaha, $1^{\text {st }}$ edition 2009 Reprint Edition 2012, Chaukhambha Orientalia, Varanasi, Chikitsa sthanaadhyaya 30/116-125 tika

3. Charaka, Charaka samhita with vidyotinihindi commentary part II by Pt. KashinathaShastri and Dr. Gorakhanath Chaturvedi, Reprint 2009, Chaukhambha Bharati Academy, Varanasi, Chikitsa sthanaadhyaya 30/70, 120

4. Charaka, Charaka samhita with vidyotinihindi commentary by Pt. KashinathaShastri and Dr. Gorakhanath Chaturvedi, part - II, Reprint 2009, Chaukhambha Bharati Academy, Varanasi, Chikitsa sthanaadhyaya 30/78-82

5. Charaka, Charaka samhita with vidyotinihindi commentary by Pt. KashinathaShastri and Dr. Gorakhanath Chaturvedi, part - II, Reprint 2009, Chaukhambha Bharati Academy, Varanasi, Chikitsa sthanaadhyaya 30/119-120 
6. Sharangdhara, Sharagdhara samhita jiwanpradahindi commentary by Dr. Smt. Shailaja Srivastava, $4^{\text {th }}$ Edition 2005, Chaukhambha Orientalia , Varanasi, Poorva khanda adhyaya $5 / 25$

7. Charaka, Charaka samhita with vidyotinihindi commentary by Pt. KashinathaShastri and Dr. Gorakhanath Chaturvedi, part - II, Reprint 2009, Chaukhambha Bharati Academy, Varanasi, Chikitsa sthanaadhyaya 30/115

8. Charaka, Charaka samhita with vidyotini Hindi commentary Part I by Pt. KashinathaShastri and Dr. Gorakhanath Chaturvedi, Reprint 2009, Chaukhambha Bharati Academy,Varanasi, Sutra sthanaadhyaya 19/5

9. Prof. Dr. V. N.K.Usha, Streeroga - vijnan (A Text Book of Gynaecology) $1^{\text {st }}$ Edition 2010, Chaukhamba Sanskrit Pratishthan, Delhi, Chapter 13

10. Charaka, Charaka samhita with vidyotinihindi commentary Part I by Pt. KashinathaShastri and Dr. Gorakhanath
Chaturvedi, Reprint 2009, Chaukhambha Bharati Academy, Varanasi, Sutra sthanaadhyaya 13/15

11. Charaka, Charaka samhita with vidyotini hindi commentary Part I by Pt. KashinathaShastri and Dr. Gorakhanath Chaturvedi, Reprint 2009, Chaukhambha Bharati Academy, Varanasi, Sutra sthanaadhyaya 27/287

12. Charaka, Charaka samhita with vidyotini hindi commentary Part I by Pt. KashinathaShastri and Dr. Gorakhanath Chaturvedi, Reprint 2009, Chaukhambha Bharati Academy, Varanasi, Sutra sthanaadhyaya 27/286.

\section{Cite this article as:}

Megha Gupta. A clinical study to compare the efficacy of dhatkyadi taila pichu and lodhradi varti in shwet pradar. Int. J. Res. Ayurveda Pharm. 2018;9(1):44-47 http://dx.doi.org/ 10.7897/2277-4343.0919

\section{Source of support: Nil, Conflict of interest: None Declared}

Disclaimer: IJRAP is solely owned by Moksha Publishing House - A non-profit publishing house, dedicated to publish quality research, while every effort has been taken to verify the accuracy of the content published in our Journal. IJRAP cannot accept any responsib ility or liability for the site content and articles published. The views expressed in articles by our contributing authors are not necessarily those of IJRAP editor or editorial board members. 